\title{
PELATIHAN TATA KELOLA WEBINAR BAGI PENGURUS DAN ANGGOTA UKK KSR PMI UNIT IAIN PEKALONGAN
}

\author{
Hendri Hermawan Adinugraha, Muhlisin, Karimaturriza, Dini \\ Syafa'ah, Dewi Sekar Arum \\ Institut Agama Islam Negeri Pekalongan \\ e-mail: hendri.hermawan@iainpekalongan.ac.id, \\ muhlisin@iainpekalongan.ac.id, ksr-pmi@iainpekalongan.ac.id
}

\begin{abstract}
Currently, technological sophistication brings new innovative ideas to educational activities. Webinars are a solution for the effective use of online learning media. Webinar governance training For administrators and members of the KSR PMI IAIN Pekalongan unit, it really needs to be delivered with an interesting method adapted to the $Z$ generation of internet generation. This community service aims to provide assistance on webinar governance as an introductory program on How to conduct online webinars and to explore digital programs during the Covid 19 pandemic which consists of training on making registration landing pages, training on making certificates quickly and training in zoom governance. Carried out by training or training methods as well as live appearances to carry out online activities. The participants were very enthusiastic in carrying out the webinar governance training event which was shown by 40 participants or $100 \%$ of the participants were happy to take part in the management training event and the results of observations made by the service team also showed that almost all participants $87 \%$ (35 participants) were able create a registration landing page, able to create certificates and e-certificates quickly and be able to operationalize the zoom application.
\end{abstract}

Keywords: management, landing pages, certificates, zoom, and adolescents 


\section{ABSTRAK}

Saat ini, kecanggihan teknologi menghadirkan inovasi ide baru dalam aktivitas pendidikan. Webinar menjadi solusi untuk efektivitas penggunaan media belajar online. pelatihan tata kelola webinar Bagi pengurus dan anggota KSR PMI unit IAIN Pekalongan sangat perlu disampaikan dengan metode yang menarik disesuaikan dengan generasi $Z$ internet generation. Pengabdian masyarakat ini bertujuan untuk memberikan pendampingan tentang tata kelola webinar sebagai program pengenalan bagaimana melaksanakan webinar secara online dan untuk mendalami program digital pada masa pandemi covid 19 yang terdiri dari, pelatihan membuat landing page pendaftaran, latihan pembuatan sertifikat secara cepat dan pelatihan tata kelola zoom yang dilakukan dengan metode training atau pelatihan serta penampilan secara langsung untuk melangsungkan kegiatan secara online. para peserta sangat antusias dalam melaksanakan acara pelatihan tata kelola webinar yang ditunjukkan oleh 40 peserta atau $100 \%$ para peserta senang mengikuti acara pelatihan tata kelola webinar dan hasil pengamatan yang telah dilakukan oleh tim pengabdian juga menunjukkan bahwa hampir semua peserta $87 \%$ (35 peserta) mampu membuat landing page pendaftaran, mampu membuat sertifikat dan e-sertifikat secara cepat dan mampu mengoperasionalkan aplikasi zoom.

Kata Kunci: tata kelola, landing page, sertifikat, zoom, dan remaja 


\section{A. PENDAHULUAN}

Akibat pandemi Covid-19 ini, para akademisi telah mengalami perubahan dalam berbagai aktivitas dan kebiasaan, perubahannya sangat cepat, sehingga civitas akademik perlu cepat beradaptasi. Perkuliahan, pelatihan, seminar, workshop, talk show hingga wisuda berjalan secara daring. Dari aspek teknis dan non teknis dalam melaksanakan kegiatan, motivasi dan tantangan dalam melakukan kegiatan online cukup berbeda. Aspek teknis dapat diamati dari ketersediaan dan keterjangkauan jaringan internet yang sesuai, ketersediaan biaya pembelian paket perangkat lunak internet, dan ketersediaan aplikasi. Sedangkan aspek nonteknis menyangkut efektivitas pelaksanaan kegiatan, termasuk kemampuan kegiatan online dalam menyampaikan informasi kepada masyarakat, sehingga khalayak memiliki pemahaman yang sama terhadap materi yang disajikan (Nurohmah dkk., 2020).

Dampak yang ditimbulkan dari adanya Pandemi Covid-19, menjadikan semua kegiatan yang seharusnya dilaksanakan secara offline terpaksa harus dilaksanakan secara online. Salah satunya seminar yang beralih menjadi webinar (seminar online) (Gunawan dkk., 2020). Dalam melaksanakan webinar ini, seluruh instansi atau organisasi, termasuk UKK KSR PMI Unit IAIN Pekalongan harus beradaptasi secara lebih intens dengan yang namanya IT. Webinar adalah kegiatan seminar yang dilakukan secara online dengan menggunakan video call dan melalui media elektronik dan internet memudahkan pembicara untuk berbagi materi. Meskipun tidak dilakukan secara langsung atau tatap muka, namun antusias peserta webinar tetap sama dengan seminar biasa. Faktanya, pelaksanaan seminar dilakukan secara online atau offline sama saja memberikan pengaruh kepada peserta yang mengikuti kegiatan tersebut. 
Sebagai warga negara milenial, sosial media sudah menjadi kewajiban untuk dipelajari untuk menunjang era modern. Dengan adanya media sosial, pelaksanaan webinar dapat berjalan lancar meskipun terhambat oleh ketentuan metode penerapan. UKK KSR PMI Unit IAIN Pekalongan telah melaksanakan program webinar yang memanfaatkan media google meet sebagai sarana komunikasi antar pengurus dan anggota. Usaha tersebut dapat dilaksanakan karena adanya pengetahuan media sosial dari para Pengurus dan Anggota. Remaja dituntut agar bisa mengetahui sistem teknologi guna memudahkan dalam kegiatan online nanti (Sutrisno., 2017).

Webinar sangat penting dilaksanakan di masa pandemic Covid-19 karena membawa banyak sekali manfaat bagi orang-orang, tidak hanya karena ada webinar yang mempromosikan Kegiatan oraganisasi mahasiswa, tapi juga setidaknya empat keuntungan bisa didapatkan (Gunawan dkk., 2020). Pertama, dalam hal efisiensi anggaran, dengan melakukan aktivitas online, panitia setidaknya dapat menghemat anggaran untuk konsumsi dan biaya akomodasi, serta menekan biaya perjalanan pemateri. Kedua, dengan melakukan aktivitas bukan tatap muka, artinya kita telah menerapkan protokol kesehatan dengan benar melalui physical distancing untuk menjaga kesehatan dan mengendalikan penyebaran virus corona. Ketiga, melalui webinar, semakin banyak orang-orang yang dapat memperoleh pengetahuan terbaru dari sumber ahli dan supervisor di bidangnya (Publik dkk., n.d.). Jika dulu jumlah peserta seminar sangat terbatas atau hanya diundang untuk berpartisipasi, melalui webinar ini siapa saja dapat mengikuti seminar, pelatihan dan bakti sosial. Meski jumlah peserta yang perlu mengikuti rapat online melalui aplikasi zoom dibatasi, namun peserta tetap akan menonton melalui channel YouTube selama siaran langsung. 
Keempat, hal yang paling menarik dari webinar ini adalah sertifikat yang didapat oleh peserta seminar (Larson \& Potter, 1995). Meski berbentuk sertifikat elektronik, sertifikat yang dikeluarkan panitia sudah resmi dan diakui bahkan untuk rekan yang berkompeten sekalipun (Herliandry dkk., 2020).

Mengingat kondisi pandemi Covid-19 maka UKK KSR PMI Unit IAIN Pekalongan melakukan penyesuaian perubahan program kerja yang semula dilaksanakan secara offline beralih menjadi online/daring. Dengan upaya melaksanakan perubahan tersebut bertujuan supaya seluruh anggota lebih berinovasi karena inovasi dalam organisasi sangatlah diperlukan agar anggota UKK KSR PMI Unit IAIN Pekalongan bisa tetap produktif dan pastinya roda organisasi tetap berjalan ditengah kondisi seperti ini. Untuk itu, supaya roda organisasi tetap berjalan di masa pandemi UKK KSR PMI Unit IAIN Pekalongan memanfaatkan platfrom media sosial. Meskipun adanya perubahan kondisi dari offline ke online, tidak semua kegiatan kami laksanakan secara online/daring. Seperti halnya rapat kerja ini bertujuan agar komunikasi antara pengurus dapat terjalin selama situasi yang sulit dengan tetap melaksanakan protokol kesehatan yang berlaku.

Sejauh ini UKK KSR PMI Unit IAIN Pekalongan masih melakukan adaptasi pada tingkat awal karena banyak hal baru yang harus disesuaikan dalam kondisi pandemi ini. Adanya inovasi baru terkait perubahan pelaksanaan sistem kegiatan yang semula dilakukan secara langsung, tapi sekarang dituntut agar dilakukan secara daring. Untuk itu kami selaku Divisi Informasi dan Komunikasi mengadakan program kerja berupa Pelatihan Tata Kelola Webinar. Pelatihan ini bertujuan agar pada saat melakukan kegiatan webinar mereka tidak mengalami kesulitan teknis sehingga kegiatan webinar yang diselenggarakan dapat 
berjalan dengan baik. Hal ini dapat menjadikan anggota lebih produktif dan kreatif dalam melaksanakan program kerja. Pelatihan ini memberikan beberapa tips dan trik kepada Pengurus dan Anggota UKK KSR PMI Unit IAIN Pekalongan terkait tata kelola webinar tersebut, mulai dari penggunaan Landing page, aplikasi-aplikasi penunjang webinar seperti Zoom Meeting, Google Meet dan sebagainya serta tata cara pembuatan sertifikat secara otomatis sehingga penggunaan waktu pun lebih efisien. Tujuan penulisan jurnal ini ialah sebagai media pembelajaran atas kegiatan webinar yang telah dilaksanakan supaya dapat memperluas ilmu kepada sesama Pengurus dan Anggota UKK KSR PMI Unit IAIN Pekalongan.

\section{B. PELAKSANAAN DAN METODE}

Tata Kelola Webinar dilaksanakan di Kampus 2 Kajen, Gedung Fakultas Ekonomi dan Bisnis Islam IAIN Pekalongan, pada hari Minggu tanggal 14 Februari 2021 dengan peserta pengurus dan anggota UKK KSR PMI Unit IAIN Pekalongan yang notabennya masih remaja yang berjumlah 40 orang. Pada usia ini bermula, remaja akan cenderung berusaha untuk mengenal jati dirinya sendiri melalui berbagai macam kegiatan (Saputro, 2017). Semangat tinggi menjadi notaben yang tidak pernah luput dari sifatnya. Dengan semangat itulah, remaja "selalu ingin tahu" berbagai ilmu baru. Remaja adalah penerus bangsa yang dapat diharapkan agar bisa memotivasi orang lain dengan berbekal ilmu pengetahuan (Pasaribu dkk., 2015). Metode yang digunakan pada pelatihan ini yaitu training atau pelatihan terkait tata kelola webinar bagi pengurus dan anggota UKK KSR PMI unit IAIN Pekalongan. Acara dimulai dengan pelatihan membuat landing page pendaftaran, dilanjut dengan pelatihan pembuatan sertifikat secara cepat dan terakhir ditutup 
dengan pelatihan tata kelola webinar. Setelah materi selesai diberikan peserta melakukan praktik secara langsung dari materi yang disampaikan oleh narasumber.

\section{HASIL DAN PEMBAHASAN}

Saat ini kecanggihan teknologi menghadirkan inovasi ide baru dalam aktivitas pendidikan. Berdasarkan berbagai riset, Webinar menjadi solusi untuk efektifitas penggunanaan media belajar online. Era big data, iGeneration mengarahakan semua kegiatan berbasis online (Zedadra et al., 2019). Kolaborasi teknologi dengan pendidikan diintegrasikan ke dalam pembelajaran online pada remaja baik di sekolah maupun di kampus. Oleh karena itu, pelatihan tata kelola webinar bagi pengurus dan anggota UKK KSR PMI Unit IAIN Pekalongan sangat perlu disampaikan dengan metode yang menarik disesuaikan dengan generasi yang ada yaitu generasi $\mathrm{Z}$ internet generation. Bahkan bagi para pebisnis yang inovatif, era digital ini juga menjadi media untuk memasarkan produk mereka serta menjadi fokus bisnis. Kolaborasi online dan bermedia teknologi informasi saat ini sangat relevan untuk dilakukan. Salah satu metode pelatihan yang tetap dapat diaplikasikan di tengah pandemi Covid-19, yakni metode pembelajaran seminar online melalui webinar (Damanik, 2020). Berikut ini beberapa kegiatan pengabdian tentang pelatihan tata kelola webinar bagi pengurus dan anggota UKK KSR PMI Unit IAIN Pekalongan yang telah dilakukan oleh tim pengabdian masyarakat pada hari Minggu tanggal 14 Februari 2021 dengan perserta pengurus dan anggota UKK KSR PMI Unit IAIN Pekalongan yang notabennya masih remaja.

\section{Pelatihan Membuat Landing Page Pendaftaran}

Agenda pengabdian masyarakat tentang pelatihan tata kelola webinar bagi pengurus dan anggota UKK KSR PMI Unit IAIN 
Pekalongan diawali dengan pembukaan oleh tim pengabdian. Kemudian dilanjutkan dengan berbagai aktivitas pelatihan dan pemberian kepada seluruh peserta pengabdian.

\section{Gambar 1.}

Penyampaian materi pembuka atau muqaddimah

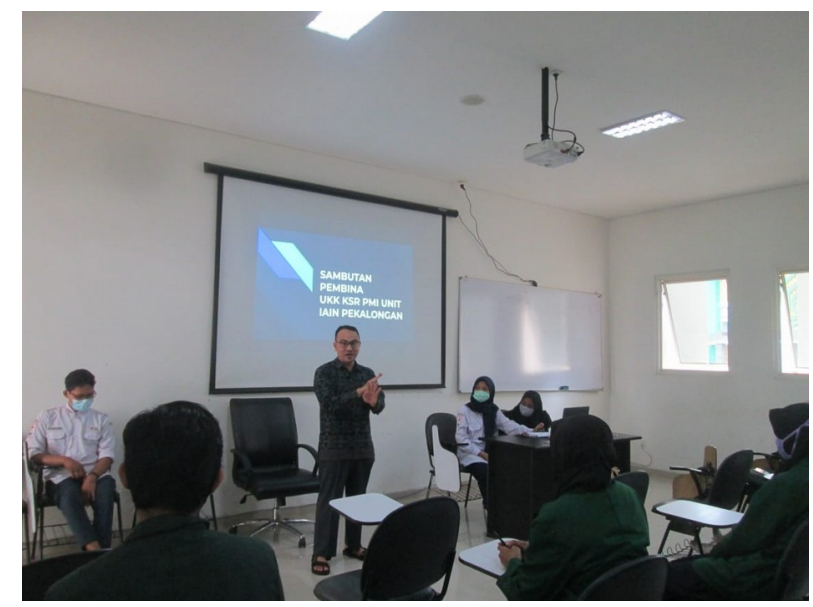

Landing page atau halaman utama merupakan suatu halaman website yang digunakan untuk keperluan tertentu. Landing page bisa dibuat dengan google sites, google sites adalah platform milik Google yang memungkinkan untuk membuat website dengan mudah. Platform ini juga gratis seperti halnya WordPress.com dan Wix.

Dibandingkan dengan platform-platform pembuatan website lainnya, hal ini karena google sites memiliki beberapa kelebihan dalam membuat website. Google Sites memiliki beberapa keunggulan, di antaranya:

1. Integrasi dengan google: Karena terhubung dengan akun Google pribadi, website yang dibuat dengan google sites langsung disimpan di Google Drive. Jadi, Kita tidak perlu susah payah melakukan backup. 
2. Tampilan admin area simple: Google sites menawarkan tampilan admin area yang mudah dipahami. Kita akan mempelajarinya di artikel ini.

3. Keamanan terjaga: Sama seperti layanan google lain yaitu gmail, google drive dan google docs, google sites aman dari virus dan serangan hacker.

4. Website cepat: Website yang dibuat menggunakan platform ini dijalankan dengan server google. Oleh karena itu, kecepatannya tidak perlu dipertanyakan lagi.

Hal ini dapat berfungsi sebagai platform pendaftaran webinar yang gunanya untuk mengabungkan bermacam-macam link yang diperlukan dalam kegiatan webinar agar peserta dapat dengan mudah mencarinya. Membuat landing page dengan google sites cukup mudah berkat menu dan tampilan yang simple dengan cara sebagai berikut:

1. Akses Google Sites

- Siapkan dulu akun google agar dapat menggunakan google sites.

- Jika sudah punya, segera saja akses google sites dan log in dengan akun Kita.

2. Buat Draft Desain Landing page

- Setelah masuk ke Dashboard Google Sites, kita menemukan beberapa pilihan template di bagian atas halaman. Dengan adanya template yang siap pakai, Kita bisa mendapatkan desain secara instan.

- Caranya membuat desain landing page yang unik dengan memilih opsi Blank untuk memulai draft landing page

3. Membuat Desain Landing page

Langkah-langkah membuat landing page atau halaman utama yaitu sebagai berikut: 
- Pertama, klik teks judul di header dan ganti dengan nama landing page. Misalnya, "Test Website".

- Kemudian, klik Text Box di tab Insert untuk memasukkan kolom teks di bawah header. Kita dapat mengisinya dengan deskripsi singkat tentang tujuan website Kita.

- Ketika kolom teks diklik, Kita dapat mengubah format teks agar sesuai tampilan yang diinginkan. Opsi formatting yang ditawarkan mirip dengan yang ada di Microsoft Word atau Google Docs, termasuk adanya pilihan bold, italic, numbering, dan bullets.

- Selanjutnya, Kita bisa mulai membuat draft halaman website tersebut. Caranya, klik dan tarik template layout dari tab Insert. Di dalam template ini, Kita juga dapat menyisipkan gambar dan teks.

- Jika ada elemen yang tidak dibutuhkan atau kurang sesuai, Kita dapat menghapusnya dengan mudah. Caranya, letakkan kursor di atasnya. Lalu, klik ikon tempat sampah di sebelah kiri elemen tersebut.

- Jika letak sebuah elemen tidak sesuai keinginan, cukup geser saja sesuai lokasi yang Kita kehendaki. Jadi, tidak perlu buru-buru menghapusnya.

- Caranya, letakkan kursor di atas elemen dan klik ikon titik-titik yang ada di sebelah kanan ikon tempat sampah tadi. Tahan tombol mouse Kita ketika memindahkan elemen tersebut.

4. Mempublikasikan Website

Apabila Kita sudah selesai dengan draft desain dan konten website, klik tombol Publish. Berikutnya, Kita diminta untuk menentukan domain website tersebut seperti gambar berikut. Pastikan nama yang Kita pilih unik agar tidak muncul pesan Langkah berikutnya, cukup klik tombol Publish. 


\section{Gambar 2.}

Penyampaian materi landing page

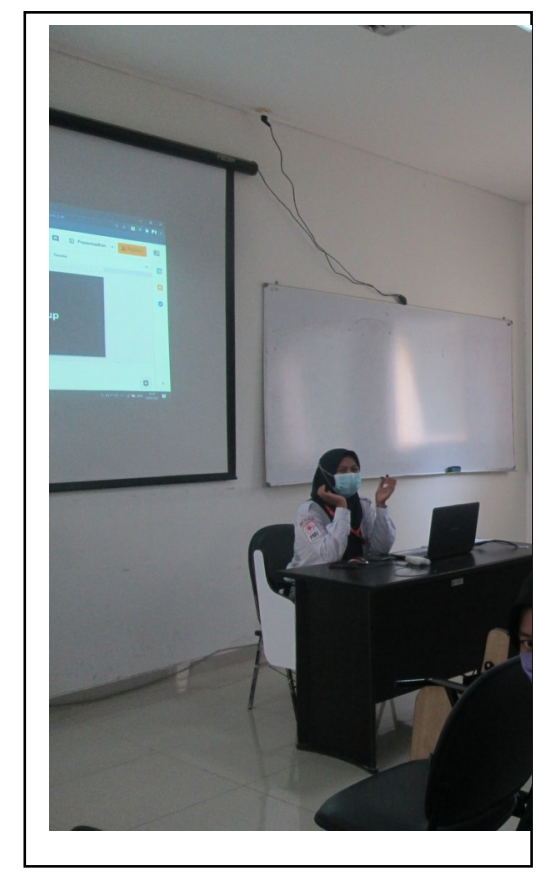

\section{Pelatihan Pembuatan Sertifikat Secara Cepat}

Dalam kegiatan webinar yang diselengarakan oleh organisasi sudah pasti terdapat fasilitas seritifikat. Sertifikat pelatihan dan webinar dibutuhkan oleh peserta untuk memenuhi nilai yang ditentukan oleh masing-masing kampus bahkan dapat berguna didunia kerja. Maka dari itu sertifikat merupakan salah satu daya tarik agar kegiatan webinar banyak diminati. Sertifikat yang dibuat sesuai dengan jumlah peserta webinar yang bisa mencapai ratusan bahkan ribuan sertifikat.

Berikut ini adalah cara cepat untuk membuat sertifikat dengan jumlah yang banyak, antara lain sebagai berikut:

1. Langakah Input Nama di Sertifikat

a. Siapkan file sertifikat dalam bentuk Ms. Word

b. Mailings

c. Select recipients 

d. Use an existing list
e. Pilih folder excel
f. Kemudian dilanjut dengan langkah selanjutnya
g. Mailings
h. Insert merge field
i. Pilih kolom nama
j. Mailings
k. Finish \& merge
1. Edit Individual Document
m. Pilih All
n. Save file menjadi .PDF

2. Langkah Rename File
a. Open PDF Split and Merge
b. Split PDF file
c. Source Pdf file: Browse > options: Split the document into single pages
d. Output folder : browse
e. Klik $\checkmark$ Split
f. Buka file nama peserta di excel > copy nama peserta
g. Buka file "rename data" di excel
h. Paste nama di kolom yg disediakan > copy file di kolom yang disediakan

i. Buka command prompt di windows $>$ arahkan ke folder sertifikat $>$ paste data excel

j. Sertifikat sudah selesai 


\section{Gambar 3.}

Praktik pembuatan sertifikat dan e- sertifikat

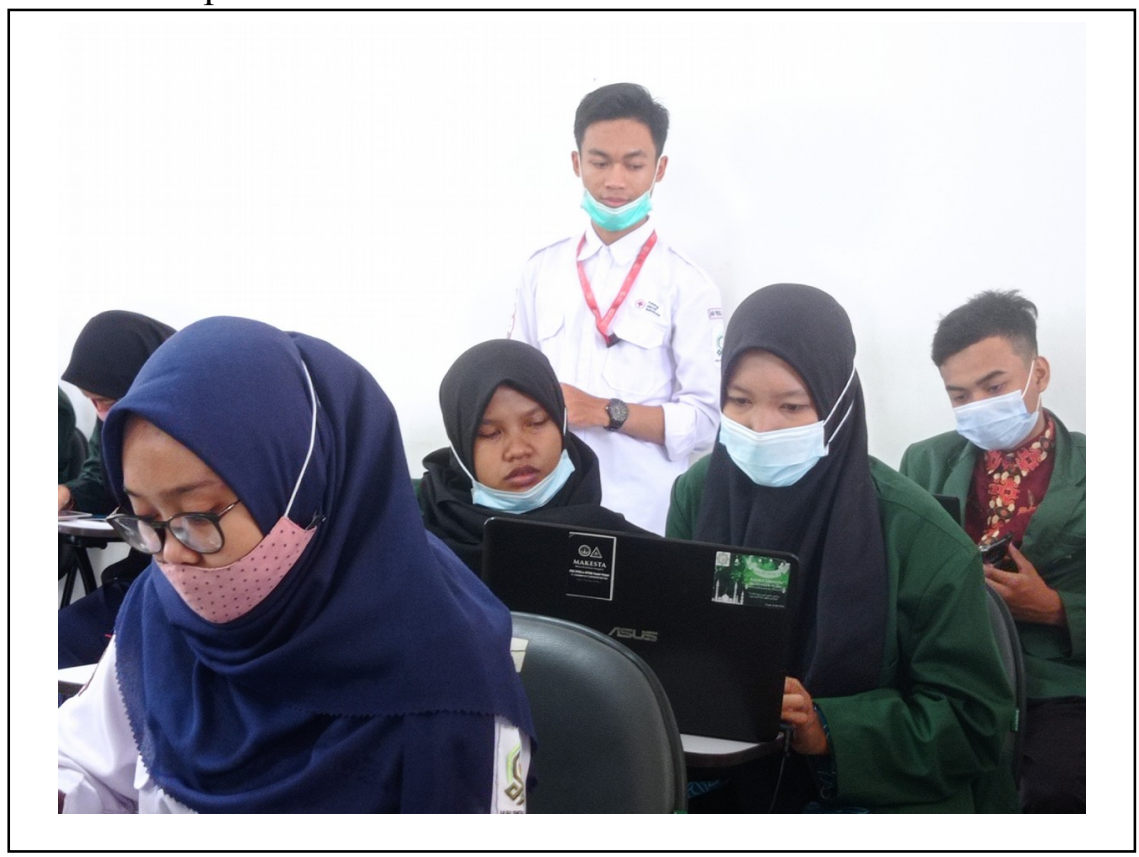

\section{Pelatihan Tata Kelola Zoom}

Istilah "video conference" mungkin tidak asing lagi bagi Kita.

Dewasa ini berbagai organisasi yang terpaksa melakukan aktivitas di rumah kerap menggunakan video conference untuk bersilaturahmi dengan rekan kerja atau anggota lainnya. Ada berbagai macam media yang bisa digunakan untuk mengadakan meeting atau video conference salah satunya Zoom Meeting.

Zoom adalah aplikasi yang dirilis oleh miliarder, Eric Yuan pada Januari 2013. Selain aplikasi, Kita juga dapat mengakses Zoom melalui situs web (untuk OS Mac, Windows, Linux, iOS, dan Android). Saat mendaftarkan diri, Kita memiliki beberapa tipe akun dasar, yang memiliki beberapa keunggulan, seperti:

1. Dapat mengadakan pertemuan hingga 100 partisipasi

2. Konferensi video 40 menit gratis untuk pertemuan rapat 
3. Jika durasinya habis, Kita dapat mengulanginya lagi

4. Kualitas gambar dan kualitas suara HD

5. Screen-sharing

6. Akses ke virtual background

7. Menjadwalkan hingga merekam keseluruhan meeting

8. Membagi partisipan menjadi beberapa "ruangan" dengan fitur Breakout Rooms

\section{Gambar 4.}

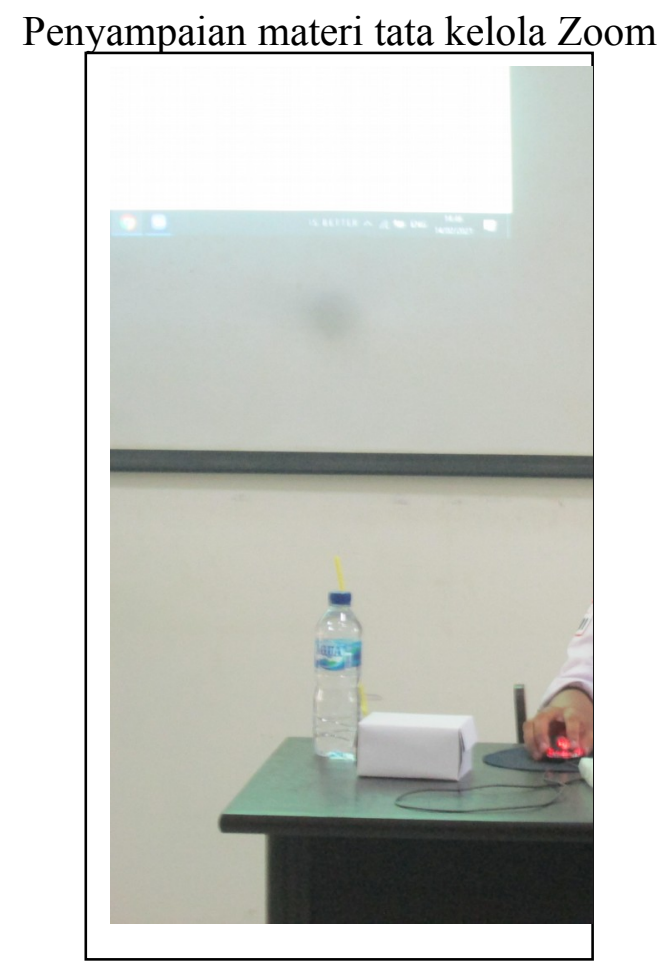

Jika Kita membutuhkan ruang pertemuan virtual selama lebih dari 40 menit atau lebih dari 100 peserta, Kita dapat menggunakan akun Pro, Bisnis, atau Perusahaan, dan harga mulai dari \$ 14,99 atau sekitar Rp200 ribuan per bulan.

Untuk menggunakan Zoom, Kita hanya perlu mendaftar secara gratis melalui aplikasi di ponsel atau situs web Kita, sebagai berikut:

Mendaftar melalui website: 
1. Kunjungi zoom.us, lalu klik tombol Sign Up.

2. Isi kolom email dengan email aktifmu, lalu cek email dari Zoom di kotak masukmu.

3. Klik "Activate Account" hingga kita kembali diarahkan ke browser untuk membuat password baru. Selamat, akun kita sudah aktif.

4. Jika sudah mempunyai akun, kita bisa memilih Sign In, lalu memasukkan email dan password yang kita gunakan untuk mendaftar Zoom Meeting.

Mendaftar melalui HP:

1. Buka aplikasi Zoom, lalu klik Sign Up.

2. Masukkan alamat email, nama depan, dan nama belakang yang ingin kita tampilkan bagi pengguna lain. Jangan lupa untuk mencentang persetujuan Terms of Service. Setelah itu, klik Sign Up.

3. Zoom akan mengirimkan email ke alamat email yang kita gunakan.

4. Klik "Activate Account" di email yang masuk dari Zoom.

5. Lalu kita akan diminta untuk menentukan password untuk akun Zoom milik kita. Selesai.

6. Jika sudah punya akun, kita bisa memilih Sign In, lalu memasukkan email dan password yang kita gunakan untuk mendaftar Zoom Meeting.

Namun, hal ini tidak hanya menjadi kendala di layar yang kecil, mengakses Zoom Meeting melalui ponsel juga memiliki kelemahan lain, misalnya foto profil tidak dapat diubah. Ya, pengoperasian mengubah foto profil dan mengedit nama karakter tunggal hanya dapat dilakukan di laptop atau komputer.

Jika Kita menggunakan laptop atau komputer, pastikan aplikasinya juga terinstal, ya. Sebab, saat menggunakan “zoom” pada browser 
dengan suatu aplikasi, terdapat perbedaan yang halus, yaitu kita dapat mengubah tampilan virtual background melalui aplikasi tersebut. Mengapa ini penting?

Jika ruang meeting yang Kita gunakan semrawut atau tidak cocok untuk meeting, Kita bisa mengubah background ruang meeting tersebut menjadi gambar pilihan Kita. Aplikasi "Zoom" menyediakan tiga latar belakang default yang dapat Kita gunakan, tetapi Kita juga dapat menyertakan gambar lain dengan rasio 16:9, dengan ukuran maksimum 5 MB.

Cara menggunakan zoom konferensi

Setelah memahami Zoom Meeting, cara menggunakan aplikasi Zoom Meeting ini antara lain sebagai berikut:

1. Kamera, baik yang sudah tertanam di perangkat pintar atau webcam terpisah. Umumnya, komputer, laptop, atau ponsel modern sudah memiliki kamera yang memadai untuk mengakses Zoom.

2. Mikrofon atau mikrofon. Sama seperti kamera, biasanya mikrofon juga ditanamkan di perangkat pintar. Kita dapat menguji suara melalui pengaturan audio di aplikasi. Jika ada masalah dengan keluaran dan masukan suara, sebaiknya gunakan mikrofon atau headset terpisah.

3. Koneksi internet. Tentunya untuk terhubung dengan rekan kerja melalui video call, nternet yang cepat dan stabil.

\section{Aplikasi} komputer, Kita mengaksesnya $\mathrm{m}$

ponsel, laptop, atau asi Zoom daripada 